\title{
PELATIHAN PEMANFAATAN INSENTIF PAJAK BAGI UMKM PADA MASA PANDEMI COVID-19
}

\author{
Vhika Meiriasari1), Mutiara Kemala Ratu1), Andini Utari Putri'1) \\ 1)Program Studi Akuntansi, Fakultas Ekonomi, Universitas Indo Global Mandiri, Palembang, Sumatera Selatan, \\ Indonesia \\ Corresponding author : Vhika Meiriasari \\ E-mail : vhikams@uigm.ac.id
}

Diterima 12 November 2021, Disetujui 27 November 2021

\begin{abstract}
ABSTRAK
Kegiatan Pengabdian Kepada Masyarakat ini dilakukan bertujuan memberikan informasi perpajakan bagi UMKM agar dapat memanfaatkan program Insentif Pajak yang diberikan Pemerintah pada UMKM di masa Pandemi COVID-19. Pada tahun 2020, ada sekitar 280.000 wajib pajak UMKM yang memanfaatkan atau sekitar 65\% dari target. Yang artinya hanya 65\% UMKM yang memanfaatkan insentif pajak tersebut. Insentif pajak merupakan kebijakan perpajakan yang diberikan oleh pemerintah kepada wajib pajak tertentu baik individu atau organisasi yang mendukung pemerintah, yang digunakan dalam memberikan dorongan dan kemudahan bagi wajib pajak agar tetap patuh dalam menjalankan kewajiban perpajakannya baik sekarang maupun di masa mendatang. Dimana Pandemi Covid-19 berdampak terhadap semua Usaha Mikro Kecil Menengah (UMKM) yang menjadi penopang perkembangan ekonomi Indonesia, banyak usaha UMKM di Indonesia mengalami penurunan omzet penghasilan bahkan sampai menutup usahanya dikarenakan kebangkrutan. Metode pelaksanaan kegiatan pengabdian kepada masyarakat ini dilakukan dengan cara Sosialisasi dan Pelatihan. Sosialisasi mengenai PMK Nomor 82/PMK.03/2021 yang kemudian dilanjutkan dengan pelatihan insentif pajak usaha mikro kecil menengah (UMKM) atau PPh final DTP. Hasil dari kegiatan ini ditemukan bahwa pelaku UMKM banyak yang belum paham cara menghitung dan menyetor Pajak Penghasilan UMKM dikarenakan terbatasnya sumber daya yang dimiliki. Dan setelah mengikuti kegiatan ini diharapkan dapat memberikan tambahan informasi dan kemampuan peserta dalam menghitung dan menyetor Pajak Penghasilan UMKM serta memanfaatkan program insentif pajak UMKM di masa Pandemi COVID-19.
\end{abstract}

Kata kunci: insentif pajak; PPh final; UMKM; lapor pajak.

\begin{abstract}
This Community Service activity is carried out with the aim of providing tax information for MSMEs so that they can take advantage of the Tax Incentive program provided by the Government to MSMEs during the COVID-19 Pandemic. In 2020, there are around 280,000 MSME taxpayers who utilize or around $65 \%$ of the target. This means that only $65 \%$ of MSMEs take advantage of these tax incentives. Tax incentives are tax policies provided by the government to certain taxpayers, both individuals or organizations that support the government, which are used to provide encouragement and convenience for taxpayers to remain obedient in carrying out their tax obligations both now and in the future. Where the Covid-19 Pandemic has an impact on all Micro, Small and Medium Enterprises (MSMEs) which are the pillars of Indonesia's economic development, many MSME businesses in Indonesia have experienced a decline in income turnover and even closed their businesses due to bankruptcy. The method of implementing community service activities is carried out by means of socialization and training Socialization regarding PMK Number 82/PMK.03/2021 which was then followed by training on tax incentives for micro, small and medium enterprises (UMKM) or final PPh DTP. The results of this activity found that many MSME actors did not understand how to calculate and deposit MSME Income Tax due to limited resources. And after participating in this activity, it is expected to be able to provide additional information and participants' abilities in calculating and depositing MSME Income Tax and taking advantage of the MSME tax incentive program during the COVID-19 Pandemic.
\end{abstract}

Keywords:. tax Incentives; final income tax; MSMEs; tax report.

\section{PENDAHULUAN}

Usaha Mikro Kecil Menengah (UMKM)

di Indonesia berkembang pesat dari tahun ke tahun dan menjadi kelompok yang sangat mendukung perkembangan ekonomi Indonesia secara keseluruhan. (Tarmidi, 2021) 
Menurut data Kementerian Koperasi dan UKM (www.kemenkop.go.id), pada Semester 1 tahun 2019 jumlah usaha mikro adalah 63.350 .222 (sebesar $98,68 \%$ dari total jumlah usaha di Indonesia), usaha kecil sejumlah $783.132(1,22 \%)$ dan usaha menengah sebanyak $6.702(0.09 \%)$. Jadi dapat dikatakan bahwa hampir 99,9 \% jumlah usaha di Indonesia didominasi oleh UMKM, dan sisanya $0.01 \%$ adalah usaha besar.

Namun pada tahun 2020 seluruh negara mengalami krisis ekonomi dikarenakan suatu wabah yang dikenal dengan Corona Virus Disease (Covid-19), semua negara mengalami penurunan ekonomi secara drastis dan tentunya berdampak di negara kita Indonesia baik secara makro ekonomi maupun mikro ekonomi. Secara mikro ekonomi, wabah Covid19 berdampak terhadap semua Usaha Mikro Kecil Menengah (UMKM) yang menjadi penopang perkembangan ekonomi Indonesia, banyak usaha UMKM di Indonesia mengalami penurunan omzet penghasilan bahkan sampai menutup usahanya dikarenakan kebangkrutan. Direktorat Jenderal Pajak telah membuat kebijakan-kebijakan perpajakan untuk mengantisipasi dampak dari Covid-19 untuk stabilitas ekonomi dan mempertahankan kepatuhan wajib pajak UMKM ditengah pandemi, dengan menerbitkan Peraturan Menteri Keuangan nomor 86/2020. (Andrew \& Sari, 2021)

Setahun berlalu, Pemerintah melalui Direktorat Jenderal (Ditjen) Pajak Kementerian Keuangan (Kemenkeu) resmi memperpanjang pemberian insentif pajak hingga akhir Desember 2021. Kebijakan tersebut tertuang dalam Peraturan Menteri Keuangan (PMK) Nomor 82/PMK.03/2021 tentang perubahan atas Peraturan Menteri Keuangan Nomor 9/PMK.03/2021 tentang Insentif Pajak untuk Wajib Pajak Terdampak Pandemi Corona Virus Disease 2019. Beleid yang telah berlaku per 1 Juli 2021 ini mengatur ada enam insentif pajak yang bisa dimanfaatkan oleh masyarakat hingga akhir tahun ini. Pertama, insentif pajak penghasilan (PPh) Pasal 21 ditanggung pemerintah (DTP). Insentif ini diberikan kepada karyawan yang bekerja pada perusahaan yang bergerak di salah satu dari 1.189 bidang usaha tertentu dapat memperoleh insentif pajak penghasilan (PPh) pasal 21 ditanggung pemerintah. Kedua, insentif pajak usaha mikro kecil menengah (UMKM) atau PPh final DTP. Dengan demikian wajib pajak UMKM tidak perlu melakukan setoran pajak tetapi cukup menyampaikan laporan realisasi setiap bulan. Ketiga, insentif PPh final jasa konstruksi DTP. Wajib pajak yang menerima penghasilan dari usaha jasa konstruksi dalam Program
Percepatan Peningkatan Tata Guna Air Irigasi (P3-TGAI) mendapatkan insentif PPh final jasa konstruksi ditanggung pemerintah. Keempat, pembebasan $\mathrm{PPh}$ Pasal 22 Impor guna mendorong wajib pajak yang bergerak di salah satu dari 132 bidang usaha tertentu. Sebelumnya 730 bidang usaha yang mendapat insentif pembebasan dari pemungutan $\mathrm{PPh}$ pasal 22 impor. Kelima, insentif angsuran PPh Pasal 25 untuk wajib pajak yang bergerak di salah satu dari 216 bidang usaha tertentu. Sebelumnya 1.018 bidang usaha mendapat pengurangan angsuran PPh pasal 25 sebesar $50 \%$ dari angsuran yang seharusnya terutang. Keenam, insentif pajak pertambahan nilai (PPN) berupa restitusi dipercepat. Pengusaha kena pajak (PKP) berisiko rendah yang bergerak di salah satu dari 132 bidang usaha tertentu. Sebelumnya 725 bidang usaha) mendapat insentif restitusi dipercepat hingga jumlah lebih bayar paling banyak Rp 5 miliar. (Hidayat, 2021)

Insentif pajak adalah kebijakan perpajakan yang diberikan oleh pemerintah kepada wajib pajak tertentu baik individu atau organisasi yang mendukung pemerintah, yang digunakan dalam memberikan dorongan dan kemudahan bagi wajib pajak agar tetap patuh dalam menjalankan kewajiban perpajakannya baik sekarang maupun di masa mendatang (Ayu, 2020). Program insentif pajak penghasilan ( $\mathrm{PPh}$ ) ditanggung pemerintah (DTP) bagi sektor UMKM digulirkan supaya sektor tersebut mampu bertahan di tengah pandemi Covid-19, bahkan agar mampu bangkit lebih baik lagi selepas pandemi. Program yang berjalan sejak bulan April 2020 hingga Juni 2021 akan terus dilakukan evaluasi lapangan oleh pemerintah. Untuk tahun 2020 itu ada sekitar 280.000 wajib pajak UMKM yang memanfaatkan atau sekitar $65 \%$ dari target. Tahun ini sudah ada sekitar 127.000 di tahun berjalan atau sekitar $27 \%$ dari target. (Hidayat, 2021)

Menurut Yuli Agustina et al., (2021) ada beberapa faktor yang menyebabkan tidak semua pelaku UMKM dengan sadar melakukan perhitungan dan pelaporan pajak. Faktor yang dirasa sangat berpengaruh kurangnya kesadaran akan Pajak UMKM yaitu:

- Omzet pelaku UMKM

Dasar perhitungan pembayaran pajak UMKM adalah pajak, yang dirasa berat bagi pelaku UMKM untuk dilaporkan. Mengingat para pelaku UMKM merasa masih baru memulai usaha dan dalam tahap berkembang dan belum memiliki keuntungan yang besar.

- Merasa tidak mendapat manfaat dari pajak 
Kesadaran akan pelaporan pajak juga dipengaruhi dengan adanya "image" bahwa manfaat dari pajak tidak secara langsung dirasakan oleh pelaku usaha UMKM.

- Kurangnya sosialisasi tentang kemudahan dan peran pajak UMKM bagi negara

Jika kita pelaku UMKM mengetahui tentang pajak maka yang ada adalah tentang kewajiban/tagihan yang harus dibayar. Bagaimana dengan peran pajak untuk Negara belum semua pelaku UMKM memahami sehingga masih perlu adanya pemahaman bagi UMKM akan peran pajak khususnya dari sektor UMKM yang memiliki kontribusi besar dalam pendapatan negara.

- Belum adanya sanksi yang tegas

Sanksi terhadap wajib pajak yang tidak menjalankan kewajiban perpajakan dirasa masih belum terlalu tegas dilakukan sehingga para pelaku Usaha UMKM tidak terbebani akan kewajiban tersebut.

Kementerian Keuangan (Kemenkeu) melalui Direktorat Jenderal Pajak (DJP) mengajak seluruh pelaku UMKM dapat memanfaatkan insentif pajak penghasilan (PPh) final ditanggung pemerintah atau DTP. Namun, bisa dilihat selama tahun 2020 hanya $65 \%$ UMKM yang memanfaatkan insentif pajak tersebut.

Rendahnya minat pelaku usaha UMKM memanfaatkan insentif pajak dapat disebabkan beberapa hal. Pertama, kurangnya daya tarik insentif itu sendiri. Selama pandemi Covid-19, banyak UMKM yang hampir tutup. Karena kurangnya pembeli, UMKM kesulitan cashflow. Memanfaatkan insentif pajak tidak secara langsung dapat memberi UMKM uang cash. Kedua, keengganan pelaku usaha UMKM berurusan dengan pajak. DJP perlu meningkatkan sosialisasi agar persepsi pelaku UMKM tentang pajak berubah dengan memberikan pemahaman lebih intensif bahwa pemerintah dapat menyediakan infrastruktur yang meningkatkan daya saing UMKM. Ketiga, kekhawatiran adanya kewajiban tambahan bagi UMKM. Masyarakat sudah terbiasa dengan semboyan 'tidak ada makan siang gratis. Karena itu, DJP perlu memberikan informasi jelas dan menunjukkan pemberian insentif itu untuk meringankan UMKM tanpa ada beban tambahan. (News DDTC, 2020)

Melalui kegiatan pengabdian kepada masyarakat ini, kami berharap dapat membantu para umkm bisa memanfaatkan insentif pajak.

\section{METODE}

Kegiatan pengabdian ini dilaksanakan pada komunitas UMKM bidang usaha kuliner/resto yang ada di kota Palembang. Kegiatan pengabdian ini tentunya menggunakan protokol kesehatan dan dibatasi hanya 20 orang peserta pelaku umkm bidang usaha kuliner/resto.

Metode yang digunakan dalam kegiatan Pengabdian Kepada Masyarakat ini menggunakan metode pelatihan. Pelatihan adalah kegiatan yang melibatkan kegiatan yang disertai dengan demonstrasi dan pengoperasian sistem atau peralatan. (Morelli, 2015)

Kegiatan pengabdian ini dilakukan melalui tiga tahap yaitu identifikasi awal, tahap persiapan, dan pelaksanaan.

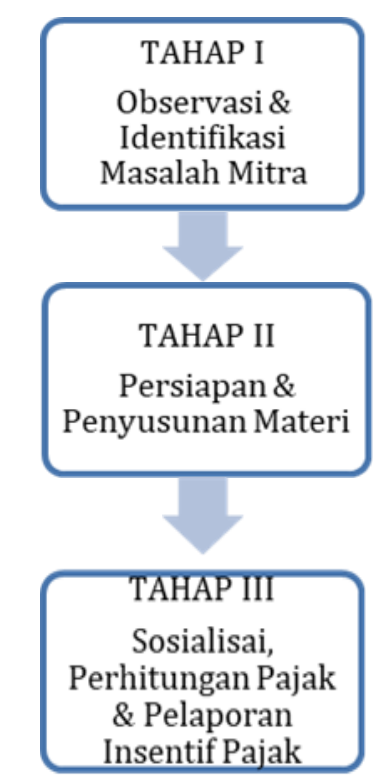

Gambar 1. Skema Pelatihan

\section{HASIL DAN PEMBAHASAN}

Pada kondisi Pandemi Covid-19, banyak UMKM yang mengeluh adanya penurunan tingkat pendapatan yang juga berdampak pada ketidakpatuhan dalam pelaporan pajak.

Oleh karena itu tujuan dari kegiatan pengabdian ini adalah untuk memberikan pengetahuan dan pemahaman dalam memanfaatkan insentif pelaporan pajak melalui pelatihan kepada para pelaku UMKM. Adapun kegiatan pengabdian dijelaskan pada tabel di bawah ini : 
Tabel 1. Kegiatan Pelatihan

\begin{tabular}{|c|c|}
\hline $\begin{array}{c}\text { Tema } \\
\text { Kegiatan }\end{array}$ & $\begin{array}{l}\text { Sosialisasi \& Pelatihan } \\
\text { Insentif Pajak UMKM }\end{array}$ \\
\hline $\begin{array}{l}\text { Hari/Tanggal } \\
\text { Kegiatan }\end{array}$ & Sabtu, 3 Juli 2021 \\
\hline Tempat & Panhead Café \& Resto \\
\hline Materi & $\begin{array}{ll}- & \text { Sosialisasi PMK Nomor } \\
\text { 82/PMK.03/2021 } \\
\text { - } \quad \text { Pelatihan insentif pajak } \\
\text { usaha mikro kecil } \\
\text { menengah (UMKM) } \\
\text { atau PPh final DTP } \\
\end{array}$ \\
\hline
\end{tabular}

Para peserta pelatihan sebelum dimulai kegiatan diberikan kuesioner berupa 10 pertanyaan seputar pajak dan insentif pajak covid-19 untuk melihat tingkat pemahaman peserta sebelum pelatihan dilaksanakan.

Adapun hasil pretest para peserta dijabarkan pada tabel 2 .

Tabel 2. Pemahaman Materi Peserta Saat Pretest

\begin{tabular}{lcc}
\hline Pemahaman & Frekuensi & Persentase \\
\hline Baik & 8 & $40 \%$ \\
\hline Cukup & 4 & $20 \%$ \\
\hline Kurang & 8 & $40 \%$ \\
\hline Total & 20 & $100 \%$ \\
\hline
\end{tabular}

Adapun kegiatan pelatihan diikuti oleh peserta dengan antusias. Kegiatan dimulai dengan memaparkan materi tentang PMK Nomor 82/PMK.03/2021 tentang Insentif Pajak untuk Wajib Pajak Terdampak Pandemi Corona Virus Disease 2019. Salah satunya yaitu insentif pajak usaha mikro kecil menengah (UMKM) atau PPh final DTP. Dengan demikian wajib pajak UMKM tidak perlu melakukan setoran pajak PPh Final $0.5 \%$. Pihak-pihak yang bertransaksi dengan UMKM juga tidak perlu melakukan pemotongan atau pemungutan pajak pada saat melakukan pembayaran kepada pelaku UMKM.

$$
\text { Pelaku UMKM yang ingin }
$$

memanfaatkan insentif ini tidak perlu mengajukan surat keterangan sebagaimana peraturan terkait, tetapi cukup menyampaikan laporan realisasi setiap bulan. Laporan realisasi disampaikan paling lambat tanggal 20 bulan berikutnya setelah masa pajak berakhir. Wajib pajak yang menyampaikan laporan realisasi melebihi batas waktu yang ditentukan, tidak dapat memanfaatkan insentif PPh Final DTP. Wajib pajak juga dapat menyampaikan pembetulan atas laporan realisasi PPh Final DTP paling lambat akhir bulan berikutnya setelah batas waktu pelaporan realisasi.

Kemudian setelahnya dilanjutkan dengan memberikan pelatihan pelaporan insentif pajak UMKM. Pelatihan ini meliputi cara membuat e-billing dan menyampaikan laporan melalui DJP Online.

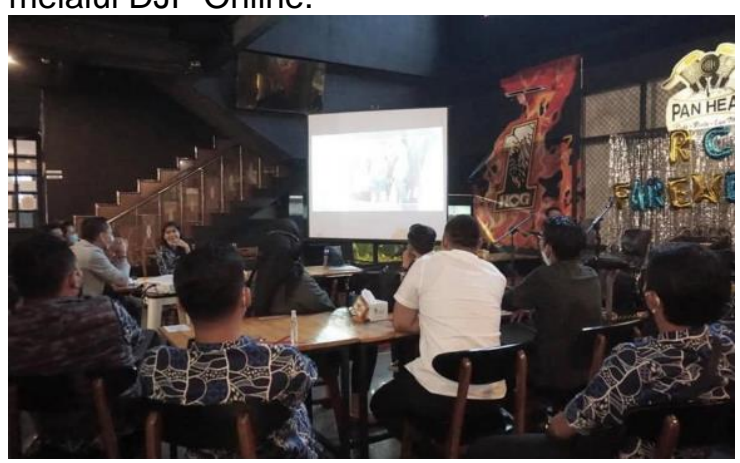

Gambar 2. Suasana Pelatihan

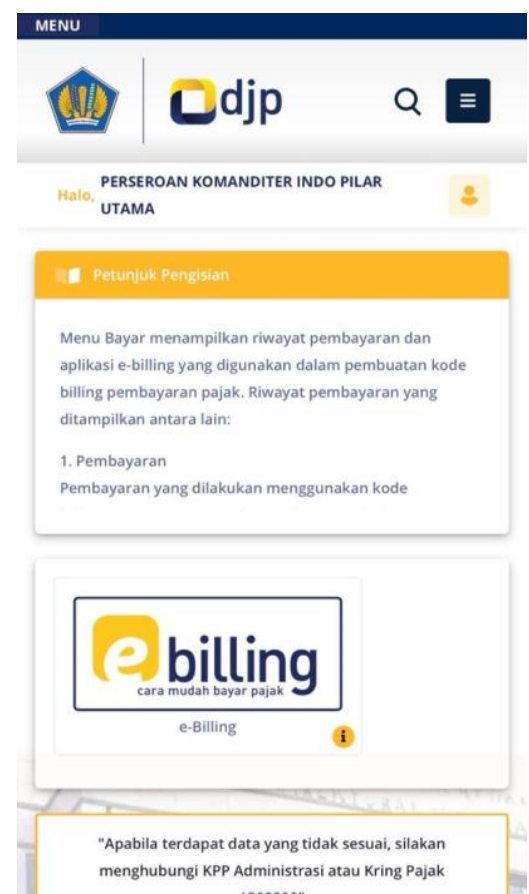

Gambar 3. Pelatihan e-billing

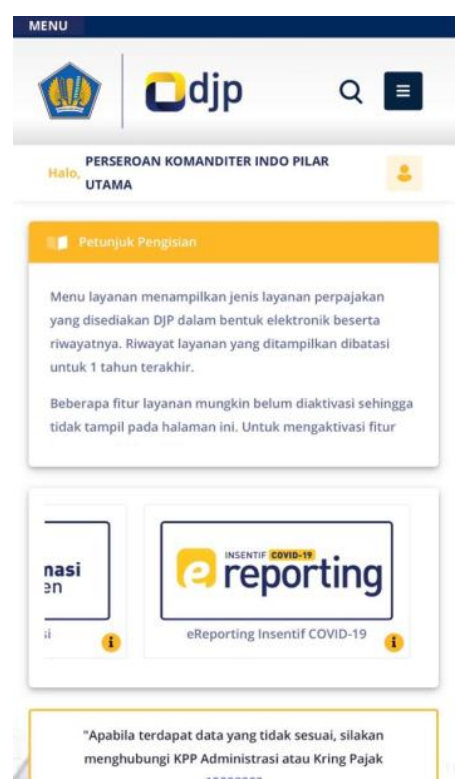

Gambar 3. Pelatihan e-reporting 
Kemudian sebelum mengakhiri pelatihan, peserta diberikan kembali kuesioner berupa 10 pertanyaan seputar pajak dan insentif pajak covid-19 untuk melihat tingkat pemahaman peserta setelah kegiatan pelatihan. Adapun hasil post-test para peserta dijabarkan pada tabel 3.

Tabel 3. Pemahaman Materi Peserta Saat Post-Test

\begin{tabular}{lcc}
\hline Pemahaman & Frekuensi & Persentase \\
\hline Baik & 14 & $70 \%$ \\
\hline Cukup & 3 & $15 \%$ \\
\hline Kurang & 3 & $15 \%$ \\
\hline Total & 20 & $100 \%$ \\
\hline
\end{tabular}

\section{SIMPULAN DAN SARAN}

Hasil kegiatan pengabdian kepada masyarakat ini menunjukkan bahwa rata-rata pelaku UMKM belum sadar pajak untuk melakukan pelaporan pajak atas aktivitas usahanya. Ditambah dengan masa pandemi covid-19 dimana banyak UMKM yang mengalami penurunan omzet, serta kurangnya pemahaman akan kewajiban perpajakannya. Karena kurangnya pemahaman para pelaku UMKM terhadap pajak, maka kesempatan pemanfaatan insentif pajak pun tidak banyak diketahui pelaku usaha UMKM.

Berdasarkan tabel 2 dan tabel 3 diatas, dapat dilihat bahwa setelah dilakukan pemaparan dan pelatihan tentang pajak dan pemanfaatan insentif pajak, kemampuan peserta meningkat. Sebelum pelatihan hanya $40 \%$ peserta yang pemahamannya baik namun setelah pelatihan, sebesar $70 \%$ pemahaman peserta dikatakan baik.

Ada baiknya pelatihan mengenai insentif covid-19 terhadap pajak umkm ini dapat dilakukan berkesinambungan mengingat pandemi covid-19 yang belum usai di Indonesia.

\section{UCAPAN TERIMAKASIH}

Ucapan terima kasih diberikan kepada Universitas Indo Global Mandiri selaku pelindung serta pendukung dalam hal finansial dalam terlaksananya kegiatan pengabdian kepada masyarakat ini. Kepada tim Panhead Café \& Bar yang telah bersedia memberikan tempat dan waktunya untuk melaksanakan kegiatan ini. Serta kepada para peserta sebagai pelaku UMKM yang telah berpartisipasi dalam kegiatan pelatihan ini. Semoga kegiatan Pengabdian Kepada Masyarakat ini dapat memberikan manfaat bagi kita semua khususnya bagi para pelaku UMKM agar dapat memanfaatkan insentif pajak yang diberikan oleh pemerintah.

\section{DAFTAR RUJUKAN}

Andrew, R., \& Sari, D. P. (2021). Insentif PMK 86/2020 Di Tengah Pandemi Covid 19: Apakah Mempengaruhi Kepatuhan Wajib Pajak UMKM Di Surabaya? Jurnal Akuntansi Dan Pajak, 21(02), 349-366. https://doi.org/10.29040/jap.v21i02.1597

Ayu, I. (2020). Pemanfaatan Insentif Minim, Apa Komentar Anda? Rebut Hadiah Rp1,5 Juta. News DDTC. https://news.ddtc.co.id/pemanfaataninsentif minim-apa-komentar-anda-rebuthadiah-rp15- juta-21953

Hidayat, K. (2021). Ini 6 insentif pajak yang diperpanjang hingga akhir tahun 2021. Diakses dari https://nasional.kontan.co.id/news/ini-6insentif-pajak-yang-diperpanjang-hinggaakhir-tahun-2021

Hidayat, K. (2021). Stafsus Menkeu: Insentif pajak UMKM adalah dukungan konkret dari pemerintah. Diakses dari https://nasional.kontan.co.id/news/stafsus -menkeu-insentif-pajak-umkm-adalahdukungan-konkret-dari-pemerintah

Morelli, N. (2015). Challenges in Designing and Scaling up Community Services. The Design Journal, 269-290. https://doi.org/https://doi.org/https://doi.or g/doi.org/10.2752/175630615X14212498 964394

News DDTC. (2020). 3 Alasan Kenapa Insentif Pajak UMKM Kurang Laku. https://news.ddtc.co.id/3-alasan-kenapainsentif-pajak-umkm-kurang-laku-25348

www.kemenkop.go.id

Tarmidi, D. (2021). Sosialisasi \& Pelatihan Penghitungan \& Penyetoran Pajak Bagi UMKM. Dinamisia: Jurnal Pengabdian Kepada Masyarakat, 5(3), 1-8. https://doi.org/10.31849/dinamisia.v5i3.4 109

Yuli Agustina, Rahman, A., \& Filianti, F. (2021). Tax Incentives: The Right Solution for MSMEs During the Covid-19 Pandemic. Wikrama Parahita: Jurnal Pengabdian Masyarakat, 5(2), 149-155. 